When ' miserable sinners'. was added to the Litany, it was probably thought to be more of rhythmical than of religious importance. Objection has frequently been made to it in later days as being unreal ; but all the same it seems to have had an attraction for each of the sets of revisers who have modified the Book of Common Prayer. It occurs five times in our present Prayerbook, and each example of its use belongs to a different period. The example in the Litany is of course the earliest, dating from 1544 ; that in the Third Exhortation at Holy Communion is derived from The Order of the Communion of 1548 ; that in the Commination Service first appeared in the Book of Common Prayer of 1549 ; that in the Prayer in time of Plague was inserted in $155^{2}$; and that in Prayers for use at Sea was added in r662. In some ways it might be considered an improvement if the English Litany were made to begin as did the mediaeval, though not the earliest known, litanies with Kyrie eleison, and the expression 'miserable sinners' omitted; but a phrase which has been so closely associated with the religious life of England for practically four hundred years, is not to be lightly discarded, and it certainly has a not uninteresting history behind it.

W. LockToN.

\title{
NESTORIUS'S VERSION OF THE NICENE CREED.
}

IN his article on 'Nestorius's version of the Nicene Creed' in the Journal for last April Dom Connolly suggests that in the clauses

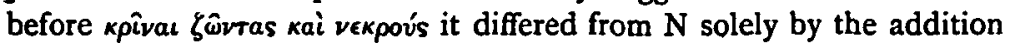

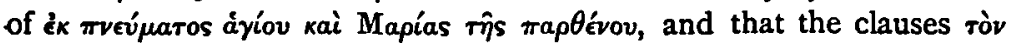

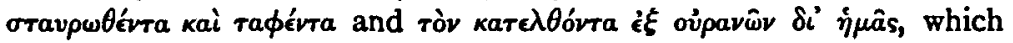
Nestorius quotes as from $\mathbf{N}$ in his correspondence with Cyril, he added 'by some sort of inadvertence' (p. 402).

On certain points we agree : that none of these clauses was in $\mathbf{N}$, and that the attribution of any of them to 'our Fathers at Nicaea' was inaccurate ; that the quotation of the first clause by Nestorius was not inadvertent ; and that it was regarded by him as authoritative. The last two points are proved by the fact that Nestorius quotes it in his letter to Celestine and in his correspondence with Cyril, and that he continues to quote it twenty years later in this Treatise of Heracleides, in spite of his having been corrected by Cyril and in spite of the canon of Ephesus. 
I do not think it possible to doubt that Nestorius regarded the clause as possessing conciliar authority, and I do not think there is any other council than that of Constantinople to which its insertion can be attributed with the least show of probability.

I must, therefore, assume that the Council of 381 added this clause to $\mathrm{N}$.

On Dr Hort's hypothesis the Council of $38 \mathrm{I}$ authorized C. Did that Council then both enlarge $\mathrm{N}$ by this clause and authorize $\mathrm{C}$, or did it only authorize $\mathrm{C}$ and so constructively add to $\mathrm{N}$ ?

There seems nothing to be said for the former view ; but, if the latter be accepted, it will follow that Nestorius is quoting this clause from $\mathrm{C}$, and $\mathrm{C}$ contained many other clauses which he did not quote.

That is, the absence of these other clauses from the quotations in the Treatise of Heracleides does not give the negative limits of Nestorius's creed ; in other words, Dom Connolly's view does not easily square with Dr Hort's, and the fact that it no more squares with mine is in consequence no argument against my hypothesis.

Secondly, as regards the other two clauses I do not think it possible to dispose of the correspondence with Cyril so lightly. They cannot be torn out of the text. Nestorius was not likely to indulge in such inadvertences in dealing with Cyril, nor would Cyril have failed to make the most of such a slip. I think it clear that for Nestorius and Cyril the three clauses stand on the same footing.

The conclusion then is this : the Council of $38 \mathrm{I}$ authorized certain additions to $N$, these were codified in the form of $E$, but it was open to any one to quote one or more of them as authoritative without casting reflexion on the remainder.

In this case Nestorius quoted the clause which was regarded as the main bulwark against Apollinarianism in opposition to Cyril and his followers, whom he regarded as Apollinarian, and in vindication of his own position. He could do no less, but to do more would be to prejudice what he regarded as the claims of truth by introducing a controversy on the status of Constantinople and its creed which Egypt, in accordance with its traditional policy, had refused to accept. Damasus had in troduced a simple clause into $\mathrm{N}$, and Nestorius might be allowed to do the same; but the danger to his cause would be increased the more alterations he made, and Nestorius did not yet know that he could claim Chalcedon on his side.

F. J. BADCOCK. 